\title{
Exploring Effective Reading Comprehension Strategies Taught in a Madarasa-cum-School in Karachi
}

${ }^{*}$ Dr. Yasmeen Sultana

** Dilawar Khan

\begin{abstract}
Reading is one of the most essential academic skills that students need in order to carry out their studies at university level. Therefore, the present study aimed to explore the effective reading strategies taught in a madrasacum-school. The study was qualitative in nature and used a case study design. In this connection, 10 teachers of a madrasa-cum-school were selected as a sample of the population. They were interviewed for 30 to 40 minutes. The interviews were transcribed, and then analyzed through thematic analysis. The findings of the research show that the teachers were familiar with the reading comprehension strategies, such as implying, inferring, predicting, making predictions; and they were applying these strategies successfully while teaching reading comprehension.
\end{abstract}

Key Words: Madrasa, Teaching Strategies, Effective reading, academic skills, school.

${ }^{*}$ Associate Professor Ilma University

** Research Scholar 


\section{Introduction}

Reading comprehension has been the most neglected area of our education system (Bhatti, 2013) which most of the teachers take for granted. It is something that both the stakeholders, teachers and students, find boring, ineffective and time consuming, which ultimately leads to the poor reading comprehension, and hence our students are not able to survive at the higher level of education. As Jarvis (2009) puts it reading skills have immense importance in students' success at school. Wenden (1985) states if students have learnt reading strategies, they can become independent learners. They do not have to rely on others. What's more, better foundation in reading at school and college level increases the chances of students' success at university (Common Core State Standards, 2010).

Unfortunately students' reading comprehension skills have been neglected especially in secondary schools in South Asia (Bhatti, 2013). In addition, students find traditional methods of language learning non-interactive (Kessler, 2007; Lamy \& Klarskov, 2011; Lan, Sung, \& Chang, 2006; Leakey, 2011). In Pakistani context reading comprehension is misunderstood at secondary and higher secondary level, where students' reading competence is gauged by asking them to reproduce the answers to the questions they have already memorized before the examination, and hence no reading comprehension examination takes place. As far as the questions are concerned, they are based on literal understanding of the text. No reading strategies such as skimming, scanning, extensive reading, intensive reading, implying, inferring are known to the students.

Since reading is commonly the most misunderstood area of a language (Bean, 
2005), students do not give enough time and attention to a challenging text. A text has three aspects of its complexity _ qualitative aspect, quantitative aspect, and reader and task aspect (Common Core State Standards, 2010). They think it is the teacher's job to teach text and at the same time the teacher thinks students are such poor learners that it is his responsibility to teach the text, and in our Pakistani context this gets much exaggerated. According to Raja (2010), teachers in our context use textbooks just as compulsion, so they read the text to the class and dictate the students the answers to the questions. Hence both the teacher and the students remain in this vicious circle and they remain there till the end of the term. As a result, the students remain poor reader throughout their whole school and college life, which affect their studies at university badly.

Reading is complex and purposeful cognitive process in which a reader uses his/her knowledge of different skills in order to construct meaning (Raja, 2013). It is not simply reading words on the page and answering the questions given at the end of the text as is the case in our society. Reading is an intricate area of a language and it should be given due time and attention (Raja, 2013).

As the researcher has been teaching English language and reading comprehension, the researcher has personally observed that reading comprehension is not given enough attention. Therefore, the purpose of the study is to investigate how to improve students' reading comprehension and to find out which strategies are more helpful in improving students' reading comprehension. 


\section{Research Questions}

The primary question of the study was:

1. What are effective reading comprehension strategies taught in a madrasa-cum-school? The secondary question was:

2. Are these strategies enough to make reading comprehension easy?

\section{Literature Review}

Different religions, especially the Hebraic religions, have given a lot importance to reading; as all these religions have scriptures to read and interpret. When Islam came to the subcontinent, the emphasis on reading increased a lot because the first word of the revelation says 'read' and the Prophet Mohammed (SAW) urged his disciples to read (USAID, 2014). Therefore, after the conquest of Sindh, the culture of reading spread throughout the region. However with the passage of time the emphasis on education became less and less. After the sub- continent was colonized by the British, only the elite class of the society could read and write, and the majority of the population was illiterate (ibid).

English speakers are categorized into three groups: those who speak English; those who were colonized by the English; and those who neither speak English nor were they ever colonized by the English (Raja, 2012). The speakers of the countries once colonized are called ESL countries. Pakistan is also one of these ESL countries. Because of colonial legacy, in the beginning English was decided on as the official language of the country. Later on it was decided that Urdu would replace English within next fifteen years (The Constitution of The Islamic Republic of Pakistan, 1973) but again 
it did not happen. English remained the official language of the country until the recent past when The Supreme Court of Pakistan gave its verdict by declaring Urdu as the official language of Pakistan and urged the Government of Pakistan to enforce it in the government offices throughout the country. Because of this crisis, the English language policy suffered a great setback in terms of English language learning and teaching. Therefore, many researches assert that English language teaching is far from satisfactory, and it is not fulfilling the needs of both learners and teachers (Warsi, 2004).

Barnett (1989, cited in Omaggio, 1993) says reading is a communicative mental process as it requires the reader's active participation in the creation of meaning and exploitation of strategies.

Day and Bamford (2000) suggest that reading is the construction of meaning from a text. According to Brummit-Yale (2008), reading is a complex mental process in which a reader uses his/her knowledge and awareness of phonemes and phonics to decode the text. Early and Sawyer (1994) assert that given three characteristics of reading are agreed upon: a) reading is the construction of meaning intended by the writer; b) reading is a mental process; and c) reading is generating meaning by using one's knowledge of syntax, semantics, and phonemes. Considering all the foregoing definitions, it can be said that reading is a process of decoding what the writer is saying; what he wants to convey and to critically think about what he writes. In other words, to decode what the writer's message is, to understand what the implied meaning is, and to think critically about the written text. 
Reading comprehension is at times a challenging activity even for native speakers, which suggests that it is not an easy skill to learn. Nevertheless, it is the most essential skill to learn (Raja, 2012). The Common Core State Standards (2010) states that even though the demands for reading have been increased in the past few years, the complexity of K-12 texts have declined in terms of sophistication and students' reading of complex and text has been ignored. This brings to light the importance of strategy instruction.

Researchers have proved that reading strategies gear up students' reading comprehension. Hamp Lyons (1985) and Kern (1989) posit that a group of students taught reading strategies did better than those who did not follow any strategy. According to Poole (2009), there is close a connection between reading strategy use and good reading comprehension. Wenden (1985) and Oxford (1990) state that reading strategies make students independent readers. According to Block (1986), reading strategies allow learners to carry out a task by identifying which textual cues they have to focus on, how to make sense of the written text, and how to resolve the reading problems.

If readers understand the ideas conveyed through the text and use them in new situations, such readers are efficient reader (Ontario, 2016). Efficient readers analyze the information critically in order to relate it to their own lives and situations. Students can become efficient readers if they learn a range of reading comprehension strategies and apply these strategies on a wide range of text types they read. Küçükoğlu (2013) confirmed that students performed well at reading comprehension after they had been taught reading comprehension strategies; these strategies consisted of implying, inferring, summarizing, predicting, visualizing, and making connections. Washington- 
Nortey (2013) confirmed that extensive reading and reading literature help students become efficient readers.

Unfortunately in our Pakistani context reading is the most ignored area of language learning (Muhammed 2011). According to Jarvis and Szmczk (2010), reading activities and tests are supposed to be time consuming and not interesting at all. Concurring to this view, Liu (2008) states that reading has always been ignored in South Asian schools, for teachers do not focus on reading strategies while teaching. Raja (2012) states that teachers in Pakistan do not take any interest in reading passages; they teach reading as a compulsion and dictate the answers to the questions given at the end of the reading passage. In addition to this, Wyatt (2012) posits that teachers do not have any command on reading and they are not trained for teaching reading.

Since a lot of research has been carried out about the importance of reading strategies in the domain of schools, and no research has been carried out about the teaching of reading skills in the domain of madaris, the present research focuses on the teaching of reading strategies in the domain of madaris. The purpose of the research is to explore how reading and reading strategies are being taught in madaris and to provide solutions to the problems in this connection.

\section{Methodology}

Since this study was exploratory in nature, the researcher used the qualitative method because it is said that the qualitative method is the best for such kind 
of researches. According to Creswell (1994), a qualitative research is a process of inquiry in order to understand a complex social or human problem. It helps us understand and interpret deeply a complex phenomenon (Denzin \& Lincoln, 1994). That is why; the qualitative method was thought to be the most useful way of carrying out the research. As a case study is a kind of research that investigates an ongoing phenomenon in its real-life context Stake (1995), the research was carried out as a case study design.

\section{Sampling}

Ten teachers of a madrasah-cum-school were selected through convenience sampling as a sample of the population. Three of them had M Phil in Islamic Studies; two of them had bachelor degree from the USA; and four had a B.A degree from Karachi. All the teachers were involved in teaching reading comprehension. Since the teaching of English at such institutes is an emerging phenomenon, the researcher chose convenience sampling for this study. Singh 7 Mangat (1996, cited in Raja, 2017) defines convenience sample as a sample that is restricted to a part of the population which is readily accessible.

\section{Data collection tool}

Interviews are very important in order to understand the given phenomenon through the interviewees' eyes. They help us understand how the interviewees perceive the given

phenomenon and what are their feelings and attitude towards it. Therefore, the researcher used structured interviews as a data collection tool in order to ensure that nothing important was missed out during the interviews. The 
questions of the interview were developed by the researcher himself. The participants of the study were asked ten questions and each interview lasted from 30 to 40 minutes. The interviews were conducted at the place they were working.

\section{Data analysis}

The interviews were transcribed and then analysed through thematic analysis. Thematic analysis is a useful process of identifying and analysing patterns and themes within a qualitative data Braun and Clarke (2006). The researcher tried to explore teachers' understanding of and their attitude towards reading strategies and how they were applying them in their classes.

\section{Reading strategies applied in the classes}

The results of the interviews show that most of the teachers were aware of the reading strategies and they were applying them while teaching textbooks. Some teachers were even teaching reading strategies separately as well. One of the teachers said,

"I think without knowing reading strategies, the students cannot enjoy the beauty of reading.

Unfortunately in our context (Pakistan) people do not have enough knowledge of these strategies. Therefore, reading for them is one of the most difficult jobs."

The teachers were applying these strategies successfully in the reading comprehension classes. Some of the strategies the teachers talked about were 
contextual clues, implying, inferring, making predictions, summarizing, and making connections. One of the teachers said,

"While teaching any passage, I try to motivate the students to try to understand the passage themselves; and when they encounter something new like some new words, I ask them to focus on the words preceding and following that specific word in order to work out the meaning. Most of the time, it helps students understand what the meaning of the given word can be in that specific context."

The teachers explained that they taught authentic texts containing different types of writing styles. For example, the texts they were teaching consisted of excerpts from newspapers, magazine articles, short stories, novels, memoirs, scientific journals and poetry. The reason behind this was to make students familiar with different kinds of text, and to teach them how to handle each text type. One of the teachers commented,

"I introduce different text types in the class and ask the students to read them by applying appropriate strategies. I ask them which text type demands scanning; which skimming; which intensive reading; and which extensive reading. This is how I teach them that reading, for example, a newspaper article is quite different from reading a literary piece of writing."

It also became known to the researcher that the teachers also focused on the inferential questions. About answering an inferential question, one of the teachers said,

"I ask them (students) to identify where the possible answer to the question 
lies. Then I ask them to read the given part of the text thoroughly in order to get a better understanding. And then I ask them to answer the question even if it not explicitly stated."

Apart from the foregoing strategies, the teachers also talked about students' critical response to the given text. They believed that reading a given text critically is also very important because it helps them become careful readers. Regarding critical reading, one of the teachers said,

"I believe it is the most important part of reading which encourages students to respond to the given text critically. It helps them understand the true value of an argument."

\section{The Effects Of The Reading Comprehension Strategies In The Classes}

One of the teachers said

"These strategies helped the students a lot. The students started taking interest in the reading texts and they were motivated to carry out the exercise. Before going through reading strategies, the students thought of reading as something outside the domain of language learning."

$100 \%$ teachers agreed that they asked the students to make use of contextual clues in order to understand the meaning of a new word. One of the teachers said,

"When the students come across a new word in the text, I ask them to read sentences that come before and after that word. I have seen this strategy 
works a lot. This we take as a riddle; and students enjoy it very much. Once they have worked out the meaning, I ask them to check their answer against the dictionary. Interestingly, most of the time the students have guessed the right meaning."

Another strategy that the teachers were using was inferring. Since the school runs the $\mathrm{O}$ Level programme, which requires the students to answer different types of questions, the teachers tried to teach how to answer different types of question in a reading passage. One of these questions is inferential questions. About the inferential questions, one of the teachers said,

"While teaching a reading passage, we focus on inferential questions as well. In order to check their understanding, sometimes I bring a daily newspaper to the class and ask them questions about the intended message of the opinion-writer. I like it when they give the right answer."

\section{Reading Strategy and Text Difficulty}

During the interviews, it became apparent that even though these strategies were helping the students in handling the reading passage, they are not the only thing which is needed to work on. The teachers were of the opinion that despite the usefulness of these strategies, they are not very helpful if the students are unable to understand the words on the page. One of the teachers said,

"Even though these strategies are very helpful, the text difficulty is the main problem that the students encounter during reading. We have seen students scoring low even though they have gone through these strategies. The main problem is the text difficulty." When asked about the text difficulty, he said, "It is as important to know what they read as what they 
have to do with

what they read. This thing is explained in the Appendix A of the Common Core State Standard.”

About the text difficulty, the same teacher said, "Again according to Common Core State Standards, a text difficulty can be measured into three ways i.e., qualitatively, quantitatively, and in terms of task. By qualitative, we mean subject matter of the text; by quantitative, we mean the syntactic structure and vocabulary; and by task, we mean the activities and exercises given at the end of the text."

\section{Students' Reading Difficulty}

When asked about students' reading problems, most of the teachers said that challenging vocabulary and longer pieces of discourse or sentences containing several modifying clauses

make reading difficult for the students. It also became apparent that at times students face difficulty while looking up the meaning of the word in a dictionary. One of the teachers commented,

"The main difficulty that the students face is that the students cannot decide on the meaning of a given a word when it has several closely connected dictionary meanings."

During the course of the interview, another difficulty that was pointed out was students' lack of cultural knowledge and social norms. Since the students did not have in-depth knowledge of English culture and their social norms, they could not arrive at the desired message of the text. One of the 
teachers explained this problem in the following way:

"Lack of cultural information is a big hurdle in students' reading comprehension. If there is a topic about, let's say, Christmas tree or Santa Claus, how can our students understand it when they have never come across such term in their real life?"

\section{Suggestion for Improving Students' Reading Difficulties}

$80 \%$ teachers believed that students' reading difficulties were because of their lack of extensive reading. They believed that students' reading difficulties can be minimized if the students are provided with enough reading materials and they are made to read extensively. One of the teachers said,

"Extensive reading is a must for students. If they want to improve their reading skills, I would suggest that they must do extensive reading. Classroom reading, in my view, is not enough to handle your reading comprehension difficulties."

In order to make the given text easier the teacher tried different strategies. Some of them focused on making analogies while some focused on paraphrasing the given text into simple English.

Regarding this, one of the teachers said,

"I break up the longer sentences into simple ones. I ask the students about different kinds of references for example, anaphoric references, cataphoric references and exophoric references. I also ask the students to define and explain the relationship between and among different kinds of modifying 
phrases and clauses."

\section{Conclusion}

The findings of the research indicate that in order to teach reading comprehension, it is not enough to teach only reading comprehension strategies. The teacher must take into consideration the complexity of the text as well. All the teachers agreed that students' reading difficulties can be minimized by developing their habit of extensive reading. During the research, it became known that no reading programme was being used in order to improve students reading comprehension. The teachers were just teaching reading strategies simultaneously during teaching from textbooks. Some teachers were also providing handouts based on reading skills.

Further research is needed to suggest different ways to make a difficult text understandable for the learners.

\section{References}

Block, E. (1986). The comprehension strategies of second language readers. TESOL Quarterly, 20, 463-494.

Brummit-Yale, J. 2012. What exactly is Reading Comprehension. K12reader.com/what-exactly- is-reading-comprehension. 13 March 2013.

Common Core State Standards. (2010).

Creswell, J.W. (1994). Research design: Qualitative \& quantitative approaches. London: SAGE Publications. 
Exploring Effective Reading lhyyā' al- 'Ulūm, Volume 21, Issue 1, Comprehension Strategies Taught in (Jan-June 2021) Madarasa-cum-School in Karachi

Day, R., \& Bamford, J. (2000). Extensive reading in the second language classroom. Cambridge: Cambridge University Press.

Denzin, N. K., \& Lincoln, Y. S. (2005). Introduction. In N. K. Denzin \& Y. S. Lincoln (Eds.), The SAGE handbook of qualitative research (3rd ed.). Thousand Oaks, CA: Sage pp. $1-29$

Early, M. and Sawyer, D.J. 1994. Reading to Learn in Grades 5 - 12. New York: Bruce, Jovanovich Publishers.

Hamp-Lyons, L. (1985). Two approaches to teaching reading: A classroombased study. Reading in a Foreign Language, 3, 363-373.

Jarvis, H. \& Szymczyk, M. (2010). Student views on learning grammar with web and book based materials. English Language Teaching Journal, 61(1), $32-44$.

Jarvis, H. (2009). Computers in EAP: change, issues and challenges. Modern English Teacher, 18(2), 51-54.

Kern, R. (1989). Second language reading instruction: Its effects on comprehension and word inference ability. Modern Language Journal, 


\section{$73,135-149$.}

Kessler, G. (2007). Formal and informal CALL preparation and teacher attitudes toward technology. CALL Journal, Taylor \& Francis: Antwerp.

Küçükoğlu, H.(2013). Improving reading skills through reading strategies. Procedia - Social and Behavioral Sciences ,70, 709 - 714.

Lan, Y., Sung, Y., \& Chang, K. (2006). Collaborative early EFL reading among distributed learners: A simulation pilot study. The JALT CALL Journal, 2(2), 53-66.

Liu, G. Z. (2008). Innovating research topics in learning technology: Where are the new blue oceans? British Journal of Educational Technology, 39(4), 738-747.

Muhammad, S. (2011). L2 reading instruction and reading beliefs of English teachers in public sector universities in Pakistan (Unpublished M.A. Thesis). Northern Arizona University, Flagstaff, USA.

Omaggio, A. (1993). Teaching language in context. Boston: Heinle \& Heinle.

Oxford, R. L. (1990). Language learning strategies: What every teacher should know. Boston: Heinle \& Heinle. 
Poole, A. (2009). The reading strategies used by male and female Colombian university students.

PROFILE Issues in Teachers' Professional Development, 11(1), 29-40.

Raja, F. U. (2017). Anxiety level in students of public speaking: causes and remedies. Journal of Education and Educational Development, 1(4), 94-110.

Raja, F. U. ( 2012). Adapting prescribed tertiary level English language books (ELT) in Pakistani classrooms. Journal of Social Sciences and Humanities, 51(1), 259-270.

Stake, E. R. (1995). The Art of Case Study Research. Thousand Oaks, CA: Sage Publications.

The British Council. (2010). Teaching and learning in Pakistan: the role of language in education. The United Kingdom's international organisation for cultural relations and educational opportunities.

Usmani, S. A. A., \& Tabassum, H. (2018). Islamic Education with the help of Information Technology: Advantages and Disadvantages. The Islamic Culture" As-Saqafat-ul Islamia" الثقافة Research Journal-Sheikh Zayed Islamic Centre, University of Karachi, (40).

USAID. (2014). Identifying barriers to reading in Pakistan. Monitoring 
Evaluation Program.

Warsi, J. (2004). Conditions under which English is taught in Pakistan: An applied linguistic perspective. Sarid Journal. Retrieved from http:// www. sarid.net/sarid-journal

Wenden, A. (1985). Learner strategies. TESOL Newsletter, 14, 1-4.

\section{Bibliography}

Abbasi, A. M. (2011). A survey of teaching strategies in ESL classroom. Language in India, 11(11), 313-329.

Awais, S., \& Ameen, K. (2013). The reading preferences of primary school children in Lahore.

Pakistan Journal of Library and Information Science, 14, 38-43.

Bhatti, S. (2016). Investigating the condition of teaching reading skill at secondary level. Proceedings of $2^{\text {nd }}$ International MultiDisciplinary Conference, Gujrat, Pakistan.

Bhatti, T. M. (2013). Teaching reading through computer-assisted language learning. The Electronic Journal for English as a Second Language, 17 (2), 1-11.

Kichou, O., \& Habri. A. (2014-2015). Application of reading comprehension strategies to develop learners' reading comprehension through use of literary texts: case study $1^{\text {st }}$ year EFL students at Abou-Bakr Belkaid Tlemcen. 
Medina, S.L. (2012). Effect of strategy instruction in an EFL reading comprehension course: a case study. Bogota, Colombia, 14(2), 79-89.

Meng, F. (2009). Developing students' reading ability through extensive reading. English Language Teaching, 2(2), 132-137.

Qarqez, M., \& Radzuwan, A. R. (2017). Reading comprehension difficulties among EFL learners: the case of first and second year students at Yarmouk University in Jordan. Arab World English Journal (AWEJ), 8(3), 421-431.

Rasheed, S., Saleem, A., Bukhsh, Q., \& Rasul, S. (2011). Identification of reading difficulties in the subject of English at secondary level: a case study of federal govt. schools. International Journal of Sciences and Education, 11(4), 680-693.

Raja, F. U. (2017). Anxiety level in students of public speaking: causes and remedies. Journal of Education and Educational Development, 1(4), 94-110.

Raja, F. U. ( year ?). Adapting prescribed tertiary level English language books (ELT) in Pakistani classrooms. Journal of Social Sciences and Humanities,vol\#?(issue?), 259-270.

Teevno, R. A. (2011). Challenges in teaching and learning of English at secondary level class $\mathrm{x}$.

International Journal of Human Resource Studies, 1 (2), 27-35.

The British Council. (2010). Teaching and learning in Pakistan: the role of language in education. The United Kingdom's international organisation for cultural relations and educational 
Exploring Effective Reading lhỵā' al- 'Ulūm, Volume 21, Issue 1, Comprehension Strategies Taught in (Jan-June 2021) Madarasa-cum-School in Karachi

opportunities.

USAID. (2014). Identifying barriers to reading in Pakistan. Monitoring Evaluation Program.

Washington-Nortey, F. M. (2013). Teaching reading comprehension in basic two: a case study of The University of Basic Schools, Legon. Retrieved from http://ugspace.ug.edu.gh 


\section{Appendix}

Questionnaire for Teachers

1. Since how long have you been teaching English?

2. How many workshops/training sessions have you attended till now?

3. Which aspect of language you consider the most important one?

4. Why are you teaching reading comprehension?

5. What are the main difficulties that face your students while reading?

6. In your view, what are the main reasons behind students' weaknesses in reading?

7. What kind of reading strategies do you try to teach in order to make your students able to handle a difficult text?

8. Which approach/es do you use while teaching reading?

9. How do you rate students' ability of reading comprehension?

10. How do you help your students deal with different types of questions in a reading comprehension test?

11. Does the literary text present in the materials pose any difficulty to the students?

12. Do you use authentic text in the class?

13. Which textbooks do you use?

14. Are they enough for your students?

15. Relying on your experience, what suggestion do you give to your students to help their reading comprehension?

16. How do you help your students deal with different types of questions in a reading comprehension test? 